\title{
Current scenario on computer-aided metalloenzymes designing
}

\section{P. Chellapandi}

Department of Bioinformatics, School of Life Sciences, Bharathidasan University Tiruchirappalli-620024, Tamil Nadu, India

pchellapandi@gmail.com

\begin{abstract}
The metalloenzymes are proteins with enzymatic activity which contain metals tightly bound in their active sites to display a chemical action. This review describes the recent developments and success of using computational methods and algorithms for designing industrial enzymes. A recent approach based on functional amino acids or peptides as characteristic molecular moieties and their conservations, has led to a significant expansion of the field of enzyme designing or enzyme mimics. Evolutionary conservation is accounted to consider designing enzymes while the metalloenzymes are a major concern due to their extensive role in catalytic activity and stability. The enzymes from methanogens may provide useful biocatalysts and may be even more valuable for biotransformation reactions, but their biotechnological applications are restricted. Therefore, a method based on the evolutionary hypothesis of conserved domain of sequences obtained from methanogens would make a significant interest in synthetic enzyme biotechnology.
\end{abstract}

Keywords: metalloenzymes designing, methanogens, evolutionary conservation.

The transitions metals are essential cofactors in the physiology of all organisms. Unfortunately, naturally available enzymes are usually not optimally suited for the industrial applications due to a lower stability of the enzymes under process conditions [1]. The protein engineering is an alternative strategy for changing different enzyme properties simultaneously [2]. The development of enzyme technology has been recently shown by a progress in the theory concerning a mode of enzymes function and how it is related to their primary structure through the formation and configuration of their $3 \mathrm{D}$ structures $[2,3]$. Generally, an enzyme design is based on the knowledge about the structure, architecture and functional properties of native enzymes. It is well known that enzymes contain a binding site and a catalytic site consisting of two or more catalytic amino acid groups $[4,5]$. Exploitation of the diverse reactivity of

(C) Institute of Molecular Biology and Genetics, NAS of Ukraine, 2011 metal center cofactors has presented a profitable strategy to introduce catalytic activity into proteins. Computer-aided enzyme modeling has taken an important effort to design metalloenzymes so as to perform chemical reactivity with good catalytic efficiency in biotransformation processes.

Several different potential reactions toward a single substrate are often exhibited on a metal centre for designing and engineering enzymes [6,7]. The successful design of small monomeric proteins [8], protein oligomers [9], and redesign of natural proteins to confer novel functionality have been achieved earlier. The generation of active biocatalysts from dramatically reduced amino acid alphabets provides a strong support for the idea that the primordial enzymes were made from only a handful of building blocks [9]. The success of current protein design methods is based largely on optimizing the packing of atoms. The proposed natural design properties were not necessary conditions for producing 
List of enzymes computationally designed

\begin{tabular}{|c|c|c|}
\hline Enzyme & Approach & Reference \\
\hline Mn-superoxide dismutase & CAChe system & [25] \\
\hline Mn-superoxide dismutase & $\begin{array}{l}\text { Molecular mechanics } \\
\text { method }\end{array}$ & [26] \\
\hline Mn-superoxide dismutase & DEZYMER algorithm & {$[7]$} \\
\hline Nuclease & $\begin{array}{l}\text { Chemical modification } \\
\text { of protein scaffold }\end{array}$ & [27] \\
\hline Protease & $\begin{array}{l}\text { Chemical modification } \\
\text { of protein scaffold }\end{array}$ & [27] \\
\hline $\begin{array}{l}\text { Deoxyribose-phosphate } \\
\text { aldolase }\end{array}$ & $\begin{array}{l}\text { Recapitulation of ac- } \\
\text { tive sites of native en- } \\
\text { zymes }\end{array}$ & [28] \\
\hline $\begin{array}{l}\text { Isochorismate pyruvate } \\
\text { lyase }\end{array}$ & $\mathrm{QM} / \mathrm{MM}$ methods & [29] \\
\hline Chorismate mutase & $\begin{array}{l}\text { Computing empirical } \\
\text { valence bonds }\end{array}$ & {$[30]$} \\
\hline Proteinase K & $\begin{array}{l}\text { Machine learning } \\
\text { algorithms }\end{array}$ & {$[32]$} \\
\hline$\beta$-Glycosidases & $\begin{array}{l}\text { Amino acid } \\
\text { replacements }\end{array}$ & [33] \\
\hline L-Aminoacylase & $\begin{array}{l}\text { Alternation of metal } \\
\text { ions }\end{array}$ & [34] \\
\hline $\begin{array}{l}\text { Co-dependent } \\
\beta \text {-methylaspartate mutase }\end{array}$ & $\begin{array}{l}\text { Molecular-evolution } \\
\text { directed approach }\end{array}$ & [11] \\
\hline $\begin{array}{l}\text { Cs-dependent formyl- } \\
\text { tetrahydrofolate ligase }\end{array}$ & $\begin{array}{l}\text { Molecular-evolution } \\
\text { directed approach }\end{array}$ & {$[12]$} \\
\hline
\end{tabular}

well-folded and perhaps even functional artificial proteins [10]. Chellapandi and Balachandramohan have introduced an in silico approach to design similar biocatalysts from small molecule mimics of enzyme active sites by combining in a small molecule with emphasis to evolutionary conservation of sequences $[11,12]$.

Structural homology-based approach is a powerful approach, which has produced a number of new designed metalloproteins [6, 13-15]. Dezymer [16, 17] and ORBIT [18] were the first computer based approaches developed for designing metalloenzymes. Metal Search [19] program has been developed to aid for designing metal-binding sites into proteins [20]. Structure-based computational design techniques have also been used to construct catalytically active sites in proteins of known structure [10]. An increa- sing effort has been made to combine rational design features into Darwinian evolutionary protocols [21, 23]. TransCent program has been developed for supporting the transfer of active sites from one enzyme to an alternative scaffold [24]. Therefore, to effectively develop a rational modeling paradigm for enzymes, detailed understanding of the mechanism of a rate determining step in the catalytic process and a comprehensive database of chemical structures with their rate data are required so far. The list of enzymes computationally designed is presented in Table. Manganese superoxide dismutase by molecular mechanics calculations (CAChe system) $[25,26]$ and rational design using DEZYMER algorithm [7], nuclease and protease by modification of protein scaffold [27], deoxyribose-phosphate aldolase by recapitulation of active sites of native enzymes [28], isochorismate pyruvate lyase by quantum mechanics/molecular mechanics [29], and chorismate mutase by computing empirical valence bonds [30] have already been successfully obtained by computational approaches. However, these approaches are more complex and used altered protein scaffold or amino acids. Unfortunately the resulting models were significantly less effective than the corresponding natural enzymes [31] and the reasons for rather limited success are not completely clear [30]. A few successful experimental enzyme designs have been made for proteinase $\mathrm{K}$ invariant by machine learning algorithms [32], $\beta$-glycosidases by amino acid replacements [34], L-aminoacylase by alternation of metal ions [34] in the recent years. Using evolutionary conservation of catalytic domain, cobalt-dependent $\beta$-methylaspartate mutase [11] and cesium-dependent formyltetrahydrofolate ligase [12] constructs from the sequences of archaea [35] have been already designed, and the designing strategy is schematically represented in Figure. Chellapandi has comprehensively reviewed the enzyme engineering and designing algorithms and associated computational programs in conceptual trends, which will ensure a competitive edge in developing improved enzymes [36].

The application of wide range of archaeon enzymes and the usage of organisms themselves in biotechnology are fairly restricted due to the complicated purification strategies and lack of expression systems. How- 


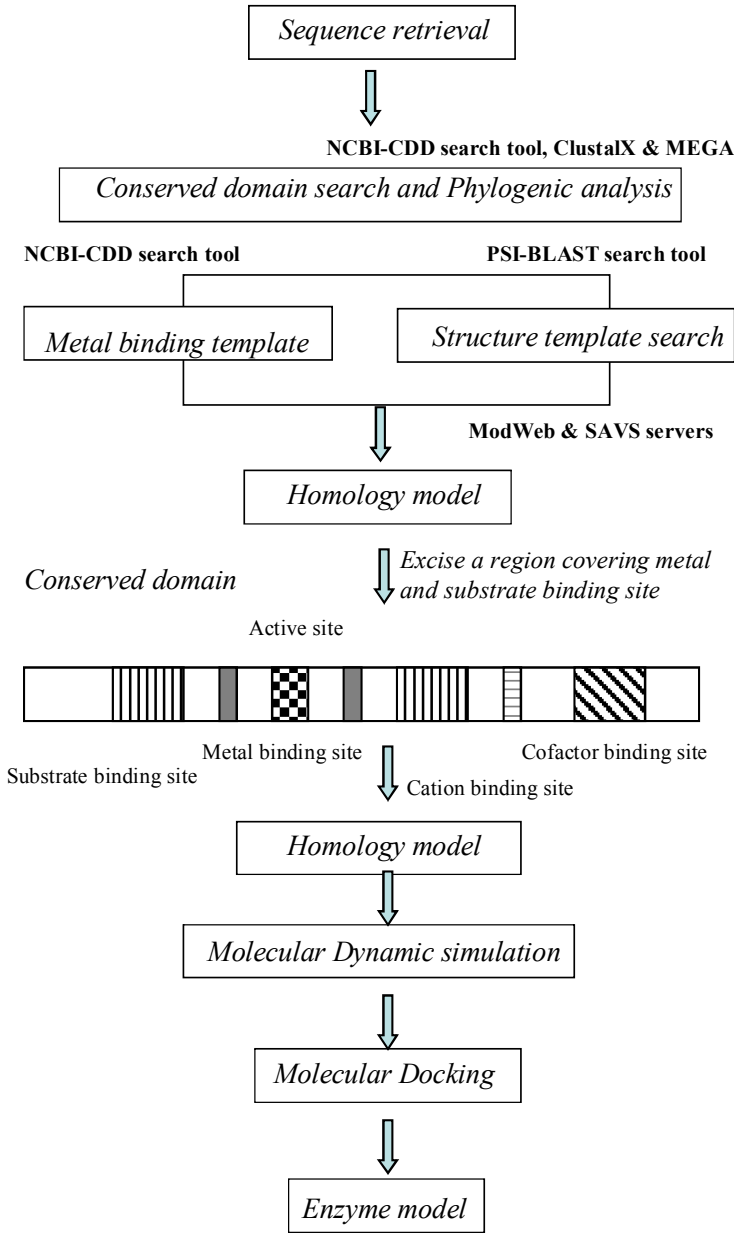

A schematic representation of enzyme designing strategy used in this study

ever, the increasing interest in applying enzymes in industrial processes has spurred the search for biocatalysts with new or improved properties. The use of biotransformation in industry will raise as it has been claimed that a doubling of the number of industrially established biocatalytic processes every decade is probable.

Acknowledgement. The author is thankful to the University Grants Commission, New Delhi, India, for financial assistance (32-559/2006) to carry out the work.

\section{П. Челлапанді}

Сучасний сценарій комп’ютерного конструювання металоферментів

Резюме

Металоферменти - це білки, що функціонують як ферменти. Вони містять метали, які взаємодіють в активних сайтах, шо забезпечує їхню хімічну активність. У представленому огляді описано останні розробки та успішне застосування комп 'ютерних методів і алгоритмів для конструювання промислових фер- ментів. Використання сучасного підходу на основі функиіональних амінокислот або пептидів як характерних молекулярних компонентів та їхньӧ̈ консервативності дозволило значно розширити сферу конструювання або імітування ферментів. Еволюиійна консервативність важлива при конструюванні ферментів, серед яких основну зацікавленість представляють металоферменти через їхню суттєву роль у каталітичній активності та стабільності. Ферменти метаногенів можуть слугувати біокаталізаторами і навіть бути ціннішими для реакцій біотрансформації, однак їхн застосування у біотехнології обмежене. Зважаючи на це, метод, оснований на еволючійній гіпотезі про консервативний домен послідовностей, отриманих із метаногенів, може стати корисним у сфері біотехнологї синтетичних ферментів.

Ключові слова: комп'ютерне конструювання металоферменти, метаногени, еволючійна консервативність.

\section{П. Челлапанди}

Современный сценарий компьютерного конструирования металлоферментов

Резюме

Металлоферменть - это белки, функционирующие как ферментыл. Они содержат металлы, взаимодействуюшие в активных cайтах, что обеспечивает их химическую активность. В данном обзоре описаны последние разработки и успешное применение компьютерных методов и алгоритмов для конструирования промыциленных ферментов. Использование современного подхода на основе функциональных аминокислот или пептидов как характерных молекулярных компонентов и их консервативности позволило значительно расширить сферу конструирования или имитирования ферментов. Эволючионная консервативность важна при конструировании ферментов, среди которых основной интерес представляют металлоферменты благодаря их значительной роли в каталитической активности и стабильности. Ферменты метаногенов могут служить биокатализаторами $и$ даже быть более иенными для реакиий биотрансформации, но их применение в биотехнологии ограничено. Вследствие этого метод, основанный на эволючионной гипотезе о консервативном домене последовательностей, полученных из метаногенов, может стать полезным в сфере биотехнологии синтетических ферментов.

Ключевые слова: компьютерное конструирование металлоферментов, метаногены, эволючионная консервативность.

\section{REFERENCES}

1. Hibbert E. G., Dalby P. A. Directed evolution strategies for improved enzymatic performance // Microb. Cell Fact.-2005.-4.P. 29.

2. Luetz S., Giver L., Lalonde J. Engineered enzymes for chemical production // Biotechnol. Bioeng.-2008.-101, N 4.-P. 647-653.

3. Monti D., Riva S. Natural and artificial microenzymes: is it possible to have small and efficient biocatalyst? // Biocatalysis and Biotransformation.-2001.-19, N 4.-P. 251-266.

4. Ilyina A. D., Ibarra-Coronado D., Gurumurthy K., Cerda-Ramarez $F$. Evidence of catalytic activity of polypeptides artificially synthesized from conservative aminoacids // Moscow Uni. Chem. Bullet.-2006.-47, N 2.-P. 134-142.

5. Lu Y. Metalloprotein and metallo-DNA/RNAzyme design: current approaches, success measures, and future challenges // Inorg. Chem.-2006.-45, N 25.-P. 9930-9940. 
6. Lu Y., Valentine J. S. Engineering metal-binding sites in proteins // Curr. Opin. Struct. Biol.-1997.-7, N 4.-P. 495-500.

7. Benson D. E., Wisz M. S., Hellinga H. W. Rational design of nascent metalloenzymes // Proc. Natl Acad. Sci. USA.-2000.-97, N 12.-P. 6292-6297.

8. Marshall S. A., Mayo S. L. Achieving stability and conformational specificity in designed proteins via binary patterning // J. Mol. Biol.-2001.-305, N 3.-P. 619-631.

9. Harbury P. B., Plecs J. J., Tidor B., Alber T., Kim P. S. High-resolution protein design with backbone freedom // Science.1998.-282, N 5393.-P. 1462-1467.

10. Looger L. L., Dwyer M. A., Smith J. J., Hellinga H. W. Computational design of receptor and sensor proteins with novel functions // Nature.-2003.-423, N 6936.-P. 185-190.

11. Chellapandi P., Balachandramohan J. Molecular evolution-directed approach for designing of $\beta$-methylaspartate mutase from the sequences of Haloarchaea // Int. J. Chem. Mod.-2011.-3, N 3.-P. 143-154.

12. Chellapandi P., Balachandramohan J. Molecular evolution-directed approach for designing archaeal formyltetrahydrofolate ligase // Turk. J. Biochem.-2011.-36, N 2.-P. 122-136.

13. Bolon D. N., Mayo S. L. Enzyme-like proteins by computational design // Proc. Natl Acad. Sci. USA.-2001.-98, N 25.-P. 14274 14279.

14. Zanghellini A., Jiang L., Wollacott A. M., Cheng G., Meiler J., Althoff E. A., Ruthlisberger D., Baker D. New algorithms and an in silico benchmark for computational enzyme design // Protein Sci.-2006.-15, N 12.-P. 2785-2794.

15. Chowdry A. B., Reynolds K. A., Hanes M. S., Voorhies M., Pokala N., Handel T. M. An object-oriented library for computational protein design // J. Comput. Chem.-2007.-28, N 14.-P. 2378 2388.

16. Hellinga H. W., Richards F. M. Construction of new ligand binding sites in proteins of known structure. I. Computer-aided modeling of sites with pre-defined geometry // J. Mol. Biol.-1991.222, N 3.-P. 763-785.

17. Hellinga H. W. Metalloprotein design // Curr. Opin. Biotechnol.1996.-7, N 4.-P. 437-441.

18. Dahiyat B. I., Mayo S. L. Protein design automation // Protein Sci.-1996.-5, N 5.-P. 895-903.

19. Clarke N. D., Yuan S. M. Metal search: a computer program that helps design tetrahedral metal-binding sites // Proteins.-1995.23, N 2.-P. 256-263.

20. Klemba M., Gardner K. H., Marino S., Clarke N. D., Regan L. Novel metal-binding proteins by design // Nat. Struct. Biol.1995.-2, N 5.-P. 368-373.

21. Voigt C. A., Gordon D. B., Mayo S. L. Trading accuracy for speed: A quantitative comparison of search algorithms in protein sequence design // J. Mol. Biol.-2000.-299, N 3.-P. 789-803.

22. Reetz M. T. Application of directed evolution in the development of enantioselective enzymes // Pure Appl. Chem.-2000.72, N 9.-P. 1615-1622.
23. Reetz M. T., Carballeira J. D. Iterative saturation mutagenesis (ISM) for rapid directed evolution of functional enzymes // Nat. Protoc.-2007.-2, N 4.-P. 891-903.

24. Fischer A., Enkler N., Neudert G., Bocola M., Sterner R., Merkl $R$. TransCent: computational enzyme design by transferring active sites and considering constraints relevant for catalysis // BMC Bioinformatics.-2009.-10.-P. 54.

25. Riley D. P. Functional mimics of superoxide dismutase enzymes as therapeutic agents // Chem. Rev.-1999.-99, N 9.-P. 2573 2588.

26. Riley D. P., Henke S. L., Lennon P. J., Aston K. Computer-Aided Design (CAD) of Synzymes: use of molecular mechanics (MM) for the rational design of superoxide dismutase mimics // Inorg. Chem.-1999.-38, N 8.-P. 1908-1917.

27. Tann C. M., Qi D., Distefano M. D. Enzyme design by chemical modification of protein scaffolds // Curr. Opin. Chem. Biol.2001.-5, N 6.-P. 696-704.

28. Zanghellini A., Jiang L., Wollacott A. M., Cheng G., Meiler J., Althoff E. A., Rothlisberger D., Baker D. New algorithms and an in silico benchmark for computational enzyme design // Protein Sci.-2006.-15, N 12.-P. 2785-2794.

29. Marti S., Andres J., Moliner V., Silla E., Tunon I., Bertran J. Predicting an improvement of secondary catalytic activity of promiscuous isochorismate pyruvate lyase by computational design // J. Am. Chem. Soc.-2008.-130, N 10.-P. 2894-2895.

30. Vardi-Kilshtain A., Roca M., Warshel A. The empirical valence bond as an effective strategy for computer-aided enzyme design // Biotechnol. J.-2009.-4, N 4.-P. 495-500.

31. Toscano M. D., Muller M. M., Hilvert D. Enhancing activity and controlling stereoselectivity in a designed PLP-dependent aldolase // Angew. Chem. Int. Ed. Engl.-2007.-46, N 24.-P. 44684470.

32. Liao J., Warmuth M. K., Govindarajan S., Ness J. E., Wang R. $P$., Gustafsson C., Minshull J. Engineering proteinase $\mathrm{K}$ using machine learning and synthetic genes // BMC Biotechnol.-2007.7.-P. 16.

33. Leon M., Isorna P., Menendez M., Sanz-Aparicio J., Polaina J. Comparative study and mutational analysis of distinctive structural elements of hyperthermophilic enzymes // Protein J.2007.-26, N 6.-P. 435-444.

34. Nishioka M., Tanimoto K., Higashi N., Fukada H., Ishikawa K., Taya $M$. Alteration of metal ions improves the activity and thermostability of aminoacylase from hyperthermophilic archaeon Pyrococcus horikoshii // Biotechnol. Lett.-2008.-30, N 9.P. 1639-1643.

35. Chellapandi $P$. Molecular evolution of methanogens based on their metabolic facets // Front. Biol.-2011.-6, N 6.-P. 490-503.

36. Chellapandi $P$. A molecular conception for protein engineering algorithms // Adv. Biotech.-2011.-10, N 7.-P. 41-46.

UDC 577.325

Received 10.05.11 